\title{
An overview of the opportunities and challenges in sustaining the energy industry in Afghanistan
}

\author{
Shambalid Ahady ${ }^{l,}$,, Nirendra $\mathrm{Dev}^{2}$, Anubha Mandal ${ }^{2}$ \\ ${ }^{1} \mathrm{Ph} . \mathrm{D}$. Candidate, Department of Civil Engineering, Delhi Technological University (DTU), India \\ ${ }^{2}$ Professor, Department of Civil Engineering, Delhi Technological University (DTU), India
}

\begin{abstract}
Energy access is not only crucial for economic growth but also important for any strategy to improve the health and social welfare of a nation. Afghanistan's energy industry is in poor condition due to many years of war and negligence. Despite international agencies' support and energy policies adopted in the last few years, Afghanistan has no universal access to power. Besides, the residences suffer from an irregular distribution of power supply. There is a growing gap between demand and supply, and the current predictions of demand do not show reality due to hindered economic growth. Afghanistan's domestic power transmission is limited, which must be extended for the country to enjoy a stable and sustainable energy supply. Sustainability and security of Afghanistan's power sector would rely on its ability to become self-reliant in power generation. Overall, the objective of this paper is to summarize the current energy status of Afghanistan and to identify energy opportunities for self-sufficiency and challenges in various aspects of energy sources. To meet energy demand, Afghanistan can develop its autochthonous hydrocarbon and renewable energy resources. By improving its domestic energy potential from natural resources, Afghanistan can fulfill its primary energy requirement. Further, along with policy formulation, appropriate and planned implementation of renewable energy policy, energy efficiency targets, and strategies, Afghanistan can reach energy self-sufficiency goals with socio-economic development.
\end{abstract}

\section{Introduction}

Asia has very significant influence on the global environment and energy trends. The energy choices made in the region have many social and health effects on nearly half of the world's population. Governmental decisions in Asia regarding energy production and consumption, energy conservation, and greenhouse gas affect energy resource depletion trends, global greenhouse gas emission levels and environmental conditions [1].

Afghanistan being a landlocked country, lies at the strategically important location. With a population of about 29.7 million (2017 update) and the total geographic area of $652,864 \mathrm{~km}^{2}$. Afghanistan is ranked at 41 st largest country in the world [2].

Four decades of conflict, civil war, foreign intervention, and political instability have constrained the country's development and have severely affected its' economic growth. However, the last decade has been characterized by remarkable progress after the security transition in 2014, but poverty increased to $54.5 \%$ [3]. Access to stable and affordable energy supplies leads to even economic growth. Energy access is crucial for any strategy to improve the health and social welfare of a nation.
During various conflicts, Afghanistan's energy infrastructure, generation, transmission, and distribution have been destroyed. The restoration and development of the nation's physical capital have been the priority of international development agencies since 2001. The progress is hindered due to the high level of damage and massive investment requirements [4]. Afghanistan is among the lowest per capita consumption of energy in the world, with fuelwood accounting for more than $85 \%$ of total energy consumption [5]. The per-capita annual power consumption in Afghanistan is $150 \mathrm{kWh}$, that is negligible to the global average of $2728 \mathrm{kWh}$. Due to the evergrowing gap between demand and supply, 85 percent of the local population in Afghanistan still does not have continuous- access to electricity supply [6]. Energy access is one of the priorities for the Afghan government and efforts have been taken for modernization and expansion of the national electricity grid with the possibility of power trade with central and south Asia. However, the national grid, due to its limited infrastructure will not be able to serve the entire population of the country in near future [7]. In this context, the objective of present study is to review the energy status of Afghanistan for the promotion of energy self-sufficiency opportunities in the country, and

Corresponding author: shambalidahady_phd2k18@dtu.ac.in 
subsequently identify the challenges that might hinder the process of achieving - energy self-sufficiency.

\section{Afghanistan's energy scenario}

\subsection{Energy demand}

The demand for electricity is growing rapidly in Afghanistan due to factors like population growth, GDP increase, energy price changes, historical changes in energy intensity, per capita consumption, domestic energy conditions, and energy availability. There is limited data on Afghanistan's rural energy consumption. The rural Afghans are poor by most countries' standards, and over $20.4 \%$ of the rural people cannot meet the minimum level of dietary energy required to sustain a healthy life [8].

Afghanistan's power sector master plan reported that the net demand is expected to rise from 2,800 $\mathrm{GWh}$ in 2012 to $15,909 \mathrm{GWh}$ in 2032 , with an average growth rate of 9.8 percent per annum, as shown in Figure 1 [9]. The predictions indicated that Afghanistan would require new energy supplies to meet the energy demand even before its domestic energy supplies develop full accessibility [6]. It is asserted that if the energy supplies are efficiently and effectively managed, then the local resources might satisfy Afghanistan's mid-term primary energy requirements (2014-15 to 2024-25). Theoretically, the domestic energy resources might let Afghanistan become Energy selfsufficient shortly [6]. According to the report, identified hydrocarbon deposits in Afghanistan can meet up to 80 percent of its requirement for petroleum products [10].

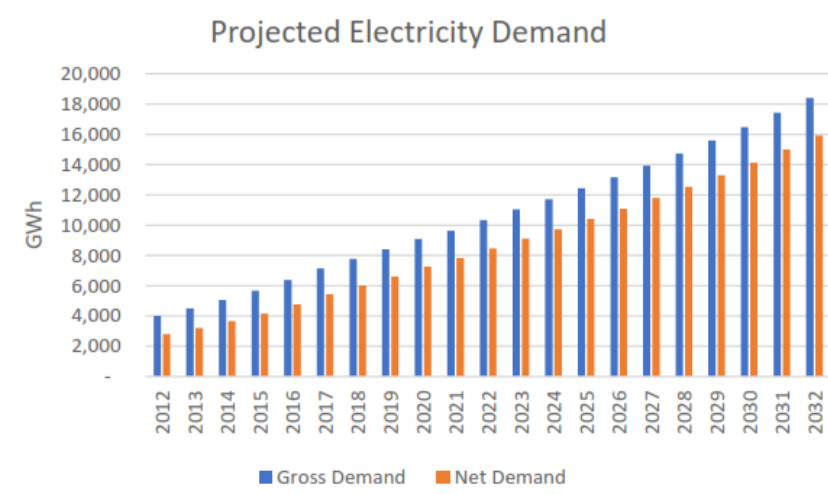

Fig 1. Afghanistan projected Electricity Demand from 2012 to 2032 [9]

\subsection{Energy supply and potential}

In Afghanistan, the current power supply system is deficient in various aspects, such as regional geographic coverage, flexibility, capability, and the cost of domestic supply [9]. Although the energy supply has almost tripled between 2006 and 2011, yet the energy access in Afghanistan is low. According to the Ministry of Energy and Water (MEW), only 30 percent of Afghanistan's population has access to energy. In Kabul the electrification is reaching 70-75 percent, but approximately $85 \%$ of the rural population does not have access to electricity required for daily needs [6]. The commercial electrical energy is supplied by kerosene, hydropower, and diesel. Hydropower and solar energy have the highest potential as a renewable source of energy, but the high initial cost is a significant hindrance [8]. The country relies heavily on electricity imports from neighboring countries, and only about $9 \%$ of the population has access to intermittent public power [5]. According to Da Afghanistan Breshna Sherkat (DABS), the domestic supply is $22.6 \%$, whereas $77.4 \%$ electricity is purchased from neighboring countries. Uzbekistan supplies (35.3\%), Tajikistan (30.7\%), Iran (21.7\%), and Turkmenistan (12.3\%). Although Uzbekistan is the largest foreign supplier, transmission capacity is constrained [11].

Table 1: Electricity imports from neighboring countries [12]

\begin{tabular}{llll}
\hline & Apr 2013- & Apr 2014- & Apr 2015-Mar \\
& Mar 2014 & Mar 2015 & 2016 \\
\hline Tajikistan & 947179 & 1137602 & 1179581.05 \\
Uzbekistan & 1392581 & 1242839 & 1356475.46 \\
Turkmenistan & 398586 & 427702 & 472958.96 \\
Iran & 839570 & 869143 & 831724.79 \\
Total Imports & 3577916 & 3677285 & 3840740 \\
\hline
\end{tabular}

With the support of the International Development Organization, Afghan authorities have significantly improved access to electricity for the residence. However, people are still suffering from a deficiency of adequate and consistent supply of electricity, domestic power, and fossil fuel production. Afghanistan's grid-connected installed capacity, it is almost divided eventually between hydropower and thermal. Off-grid renewables (large hydropower, solar, wind, and biomass) offer a balanced amount of energy. Out of $623 \mathrm{MW}$ installed domestic capacity, $312.5 \mathrm{MW}$ is from thermal, $255.5 \mathrm{MW}$ is from hydropower, and $55.0 \mathrm{MW}$ is from renewable energy as shown in Figure 2 [12].

\section{Total Installed Domestic Capacity in MW}

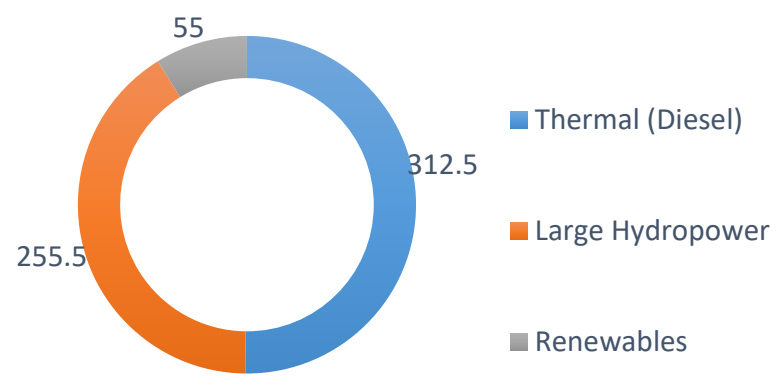

Fig 2. Sources of electricity in Afghanistan- Total Installed Domestic capacity in MW

The energy sector in Afghanistan is dominated by expensive fuel oil and diesel generation, which is costly. It can cost up to 35-40 U.S. cents per kWh and about 6 to 7 times higher the price of the electricity being imported from Central Asian countries [6]. Due to the lack of grid integration, the existing thermal generation capacity is costly to operate and increases dependence on different import sources though in recent years, the government has invested in renewable energy sources. The import bill of energy has increased 14 times from \$16 millions to \$224 
millions from 2007 to 2015.The electric supply, i.e. domestic vs import has been shown in Figure 3.

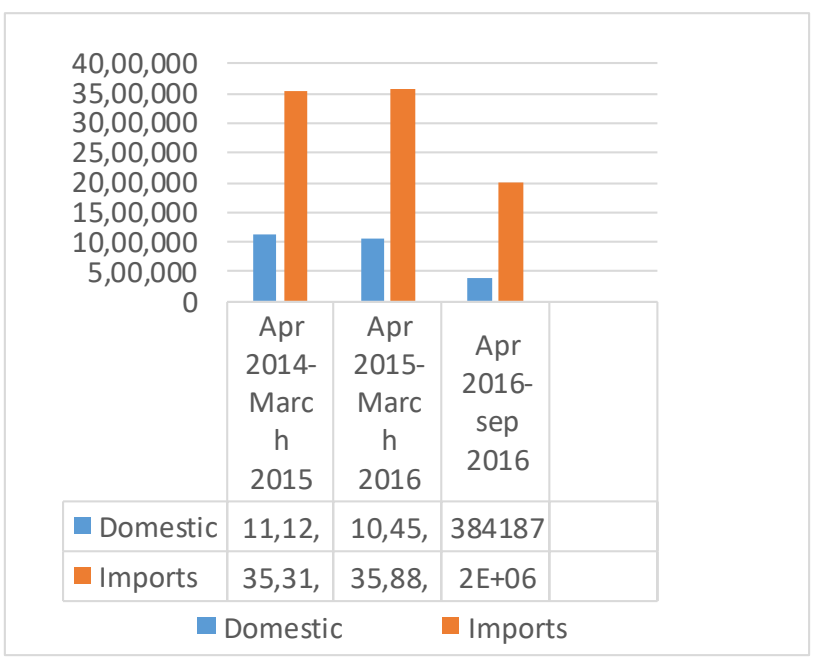

Fig 3. Electricity supply MWh (Domestic vs Imports)

Table 2 and Figure 4 gives the cost of supply, i.e. the average estimated unit price in Usc $/ \mathrm{kWh}$ [8].

Table 2. Cost of Supply [8]

\begin{tabular}{lll}
\hline S/N & Type & $\begin{array}{l}\text { Avgerage Unit } \\
\text { Price (Usc /kWh) }\end{array}$ \\
\hline 1 & Diesel (all provinces) & 29.53 \\
2 & Thermal (NW Kabul) & 27.115 \\
3 & Hydro, thermal and Diesel & 6.473 \\
4 & Hydro and Diesel & 5.19 \\
5 & Natural gas & $2.8-3.5$ \\
6 & Imported & 2.62 \\
7 & Hydro & 2.29 \\
8 & Coal (1MW=4.5ton) & 1 ton=Afs 2.200 \\
\hline
\end{tabular}

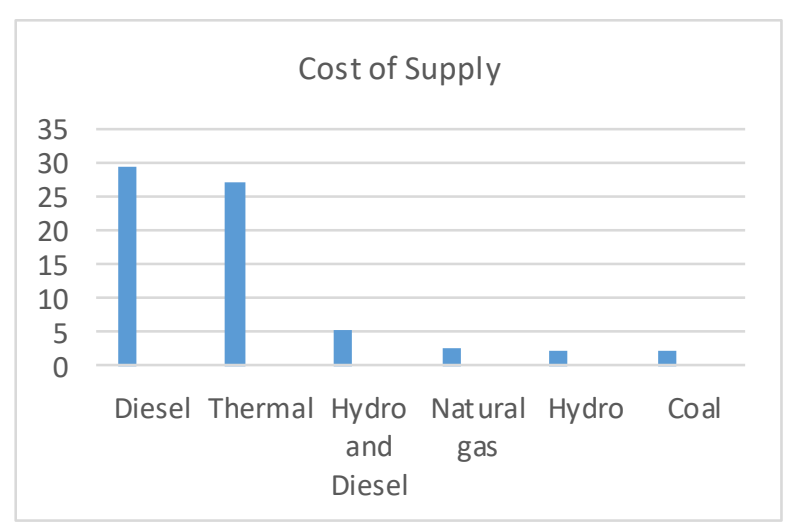

Fig 4. Cost of supply [13]

\section{Transmission and distribution}

The least developed part of the Afghan power system is the power transmission and distribution. The transmission system is independent grids or islands supported by various power systems and import sources. It has been noticed that between 2010 and 2015, number of household connections to the grid has increased by $60 \%$, and the total number of connections has increased by $57 \%$. Out of the total connections, $93 \%$ are households, and rest $7 \%$ are commercial customers and government agencies. Da Afghanistan Breshna Sherkat (DABS) is the only independent state-owned utility in the country owning all the infrastructure of the generation, distribution, and transmission in Afghanistan.

For operational purposes four major working groups link various supply sources to the grid for operational purposes, (i) NEPS (North East Power System) comprising of several small islands, connects 17 load centers which include Mazar-e-Sherif,Kabul, and Jalalabad with Uzbekistan and Tajikistan (at $110 \mathrm{kV}, 220$ $\mathrm{kV}$, and $35 \mathrm{kV}$ ); (ii) SEPS (southeast Power System) comprising of Khandar and linking with Kajaki $(110 \mathrm{kV})$; (iii) HS (Herat System) which links Iran with Turkmenistan (132 kV and $110 \mathrm{kV})$; and (iv) TS (Turkmenistan System ) that links Andkhoy, Herat, Faryab, JawzJan, and Sar-e-Pul, districts (110 kV) [9].

Distribution networks in areas apart from NEPS also need to be rehabilitated as those were destroyed during conflict or have exhausted their economic life causing technical losses [5]. Hence, for the major urban centers, the main focus has been the rehabilitation and expansion of the distribution system. It is seen that each new connection is expensive and costs about $\$ 1,000$ in distribution alone. Also, due to the weak distribution systems, there is a power wastage of up to $75 \%$ [14].

A focus of the development of energy sector efforts has been to upgrade Afghanistan's electricity grid from isolated islands into a national transmission grid. A unified grid will make the transmission of power generated from one part to another of the country. It will also ensure that imported power can be transmitted to the remote area of the country. Table 3 gives the existing and the planned transmission line lengths as per the source.

Table 3. Existing and planned transmission line lengths [13]

\begin{tabular}{llll}
\hline $\begin{array}{l}\text { Line } \\
\text { Voltage } \\
\text { KV }\end{array}$ & $\begin{array}{l}\text { Existing/ } \\
\text { Km }\end{array}$ & Planned / km & Total/km \\
\hline 13.2 & 2 & & \\
20 & 80 & - & 2 \\
35 & 78 & - & 80 \\
110 & 1,287 & - & 78 \\
132 & 148 & - & 4,128 \\
220 & 669 & 2,667 & 148 \\
500 & - & 1,393 & 3,336 \\
Total & $\mathbf{2 , 2 6 1}$ & $\mathbf{6 , 9 0 7}$ & 1,393 \\
\hline
\end{tabular}

\section{Energy resources and consumers}

Hydropower is one of the widely used renewable energy. Due to water resources availability and environmental benefits, hydropower plants have attracted particular attention. As discussed earlier, access to power is limited in Afghanistan though it has considerably improved in the past few years. There is a very high per capita consumption of fuelwood and charcoal due to high altitude and severe winter conditions, which has increased to more than 10 tons/year for households in some cases. The average households in the rural areas of Afghanistan frequently lack an adequate amount of fuel for cooking. In 
rural areas, solid biomass is the primary fuel; on the other hand, wealthier families frequently use fossil fuel as a part of their energy portfolio. Utilization of solid fuel is related to major health issues and results in natural resource depletion. As per DABS, there was $8 \%$ increase in the number of connections by 2015 , and there has been an approximately $4 \%$ year on year increase [15] [16]. Table 4 presents a number of DABS Electricity connections.

Table 4. Number of DABS Electricity connection [16]

\begin{tabular}{llll}
\hline Type of usage / Year & $\mathbf{2 0 1 3}$ & $\mathbf{2 0 1 4}$ & $\mathbf{2 0 1 5}$ \\
\hline Household & $1,009,445$ & $1,112,833$ & $1,197,388$ \\
Commercial & 77,980 & 82,467 & 87,694 \\
Government & 13,999 & 15,643 & 17,011 \\
Total & $1,101,424$ & $1,210,943$ & $1,302,093$ \\
\hline
\end{tabular}

Various factors determine choices for the energy system that includes technology, cost, accessibility, politics, demographics, convenience, and safety.

\subsection{Renewable energy technologies}

In Asia, renewable energy technologies viz. hydropower, solar, thermal, wind, and traditional biomass have been well-establish. According to the International Renewable Energy Agency (IRENA), the renewable energy power generation capacity in Asia increased from $387550 \mathrm{MW}$ in 2010 to $918655 \mathrm{MW}$ in 2017 [17]. Figure 5 depicts the total renewable energy capacity in Asia. Figure 5 comprises the renewable power generation capacity by the source in Asia during the years 2010 to 2017.

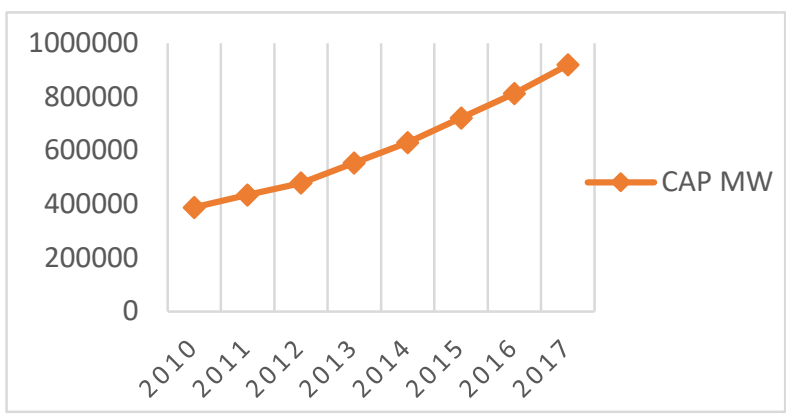

Fig 5. Total renewable energy capacity in Asia [17]

Renewable energy will be vital in the economic, social, and sustainable growth of Afghanistan. The renewable resources such as biomass, hydro, and solar are available in plenty, and their exploitation would help in improving the future supply gaps in terms of both economic and financial conditions. Figure 6 demonstrates the total renewable energy capacity and growth in Afghanistan from 2010 to 2017.

According to World Bank, Afghanistan's hydroelectric capacity 23,000 MW out of which about $87 \%(20,000$ MW) is located in the north-east on the Amu Darya, Panj, and Kokcha rivers. About $8 \%(1,900 \mathrm{MW})$ is located to the east of Kabul, half of which is - on the Kunar river [9]. Installed Hydro projects of the capacity of up to 3 Megawatts. Table 5 shows the Hydro project's capacity [18].

Afghanistan's average solar-energy potential is about $6.5 \mathrm{kWh}$ per $\mathrm{m}^{2}$ per day, with approximately 300 days of sunshine per year. Higher values of solar potential is available in the southern areas of Kandahar, Farah, Herat, and Helmand provinces. Electricity generation is technologically feasible even in the northern provinces where average irradiance is only $4.5 \mathrm{kWh}$ per $\mathrm{m}^{2}$ per day [9].

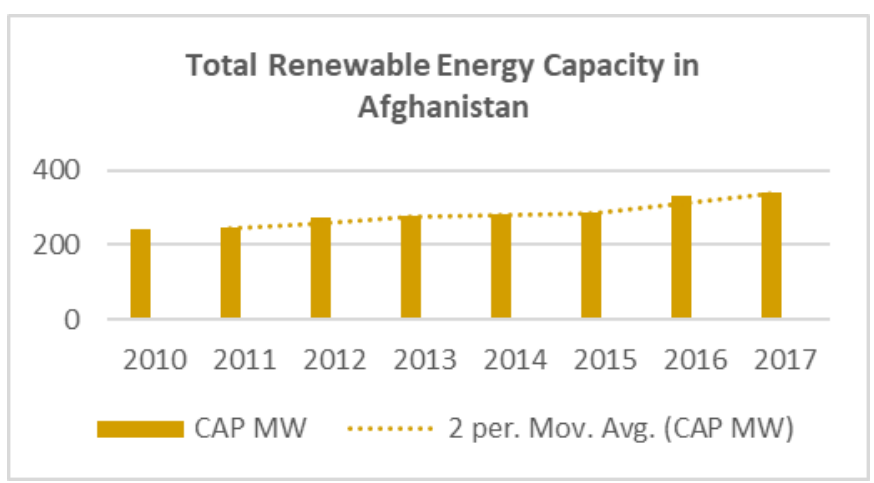

Fig 6. Total renewable energy capacity in Afghanistan, [17]

Table 5. Hydro Projects [16]

\begin{tabular}{ll}
\hline Type of Hydro project & Capacity (MW) \\
\hline Small & $<25000 \mathrm{~kW}$ \\
Micro & $<2500 \mathrm{~kW}$ \\
Micro & $<250 \mathrm{~kW}$ \\
Pico & $<2.5 \mathrm{~kW}$ \\
\hline
\end{tabular}

The wind resources also have considerable potential in Afghanistan, but it is concentrated in the southwest near the Iran border. The nation's total wind energy capacity is $150,000 \mathrm{MW}$, whereas exploitable capacity is estimated to be $66,700 \mathrm{MW}$. Also, there are signs of the significant potential of geothermal and biomass, but further study of such sources of energy is required [9]. To meet the energy needs of citizens, biomass plays an essential role since fuel demand is in the form of fuelwood, charcoal, animal manure, and crop residues, mainly utilized by households. Geothermal Energy for power generation can be harvested at a low cost. Table 6 shows the potential for renewable energy resources in Afghanistan.

Table 6. Potential for Renewable Energy in Afghanistan [18]

\begin{tabular}{l|l}
\hline Type of Energy & Potential \\
\hline Solar & 222000 Megawatts \\
& $\begin{array}{l}\text { Average solar insolation of } 6.5 \\
\mathrm{kWh} / \mathrm{m} \text { per day } \\
\text { 300 days of sunlight }\end{array}$ \\
\hline Hydropower & 23000 Megawatts \\
& $\begin{array}{l}\text { Potentials of large Dams, Mini and } \\
\text { Micro potential each 600 Megawatts }\end{array}$ \\
\hline Wind & 67000 Megawatts \\
& 36000 Km \\
& 5 MW per Km, windy land \\
\hline Biomass & 4000 Megawatts \\
& Animal waste 840 Megatts \\
& 3090 Megawatts agriculture waste \\
\hline Geo-Thermal & 3000-3500 Megawatts \\
& 3 big possible regions \\
& 4-100 Megawatts \\
\hline
\end{tabular}

\section{Energy policy}

Afghanistan is rebuilding its energy sector. Since 2004, the Afghanistan government, along with the international 
community, has been developing the National Development Strategy, and the energy sector has been in top priority. The Afghanistan National Development Strategy (ANDS) was adopted in 2008 to address the challenge of coordinating among various domestic agencies and their international partners for the transformation of the electricity sector [19].

The National Integrated Energy Policy adopted in 2016 , provided broad guidelines on the scope for the energy sector in Afghanistan and made Ministry of Energy and Water (MEW) the apex agency for developing and implementing energy policy [20].

Ministry of Energy and Water (MEW) has also developed the Renewable Energy Policy, which envisages the mainstreaming of renewable energy projects in the development of the energy sector. The policy permits investors to generate electricity based on renewable energy resources at one or multiple locations and receive an equivalent amount for own use elsewhere on the grid after accounting for transmission losses and wheeling charges. The policy also deregulates small scale power production projects through renewable resources up to $100 \mathrm{~kW}$ [18] Although the government has adopted energy policies and strategies for power generation and energy efficiency, yet there has been limited focus on energy conservation and has not implemented energy efficiency policy in a different sector. Additionally, cooking, and heating devices in households are based on either renewable energy sources or traditional biomass that can support the country's energy demand.

\section{Challenges in reaching self-sufficiency}

Every nation has a different path for achieving the energy requirements and following the transition to a sustainable energy sector. It involves a unique mixture of source opportunities and challenges related to access and efficiency. Afghanistan's energy challenges are somewhat different from other developing countries due to reasons noted earlier. Afghanistan is energy deficient nation, which can be seen from its domestic power generation capacity provided only 22 percent of country total consumption till 2015. Afghanistan is facing many challenges viz. economic and political problem due to insurgency, decreasing economic growth, and unending poverty. Also, Afghanistan's public electricity sector is facing problems related to workforce and technical capability [21].

- Afghanistan lacks policy frameworks that specify the provision of energy for sustainable development. There has been difficulty in implementing the existing policies and enforcing the laws because of poor infrastructure which poses many challenges in promoting energy efficiency.

- There is an irregular distribution in the country because of which the Afghan consumers are suffering. Presently, about 70 percent of consumers in the city of Kabul receive a continuous supply of electricity, while about two-third (67-75 percent) of the country's population do not get the regular power [22].

- The country has a limited capacity of transmission and distribution networks, that needs to be extended in order to have much energy security. The number of household connected to the electricity grid was 1,176,030 in March 2015 and has been increased by 11 percent in the past few years. Further the government's power extension policy has increased the transmission lines length from $2,261 \mathrm{~km}$ to 6,907 $\mathrm{km}[16]$.

- Accessibility to the water resources under the uncertainties of climatic - for future hydropower generation is a major apprehensions in the country's long-term energy planning [9].

- The absence of funding in gas production and transmission infrastructure limits the expansion of the gas reserves of 75 billion cubic meters to only 150 square kilometers area. Substantial renewable energy and fossil fuel resources are essential for development through private and public investment [23].

- Since several organizations are involved for the administration process, authorizing procedures and maintenance activities lead to coordination problems among the various authorities.

- There is limited public awareness and responsiveness of renewable energy technologies, social advantages, and environmental benefits along with the accessibility to inexpensive fuel energy resources.

\section{Self-sufficiency opportunities}

The self-sufficiency goal in the energy industry in any region can be achieved through the government's well laid - vision and objectives to produce enough energy locally. Demand stability -can be achieved through supplying even, secure, and high-quality energy services to Afghan citizen and by promoting renewable energy and energy conservation measures in different sectors.

\subsection{Best use of autochthonous hydrocarbon and renewable energy resources}

Afghanistan has plentiful fossil fuel and renewable resources that need to be exploited for meeting the energy requirements. The adoption of national and regional policies can play an essential role in supporting autochthonous hydrocarbon and renewable energy development and implementation. It will help the nation in identifying the priorities and ways to construct a sustainable and cost-effective energy market.

Renewable energy, including hydro, solar, wind, geothermal, biomass, and wood offers the greatest hope for Afghanistan. However, despite of its potential, hydropower is still untapped in many parts of Afghanistan. The country's annual renewable surface water resources are estimated at 57 billions $\mathrm{m}^{3}$, which is distributed across five river basins. Nonetheless, the water resources are unevenly distributed across the country or not equally accessible - throughout the year [24][25] There has been evidence that geothermal and biomass have considerable potential [9]. Providentially, the government, with the support of the international community, is setting specific targets for the renewable energy sector by supporting national and international companies to meet the country's energy demand and reach self-sufficiency in the near future. 


\subsection{Energy efficiency and conservation}

Developed countries have proven that energy can be wellpreserved by reducing the amount of wastage and losses, enhancing efficiency through technological advancements, and improved operation and maintenance [26]. The effective way to fill the energy demand gap in Afghanistan would prompt energy efficiency through rehabilitation, implementation of useful technologies, and construction of energy-efficient cities. This will decrease the energy consumption and lead to cost-saving after an off-set from the initial investment cost. Other than the financial benefits, energy-saving may contribute to environment protection through the reduction of emission of greenhouse gases. Energy conservation decreases the energy demands which in turn helps in increasing the quality of the environment, national security, personal financial security and cost savings. Therefore, the government needs to improve energy efficiency by focusing on application mechanisms in different sectors, and should follow energy efficiency policies more conscientious energy efficiency in the building sector will play a significant role in energy conservation since buildings consume a high level of energy. Along with other initiatives, enhancing energy efficiency is the cheapest, fastest and most environmental friendly way to meet a substantial amount of Afghanistan's energy requirements and will, therefore, reduce the need for investing in the energy supply.

\section{Conclusion and recommendation}

Currently, Afghanistan is not an Energy self-sufficient country. However, the Afghan government, along with the international communities is exploring the possibilities to achieve it.. -Afghanistan's energy status can be described as a prolonged 'energy poverty,' i.e., lack of access to modern energy services. Energy access is low in the country which has - considerably improved in the last few years. Renewable energy resources are abundant, such as hydro, wind and solar, but they are still untapped. The costs of exploitation of such resources have fallen in recent years, and hence can be explored by the government. Access to reasonable and uninterruptible electricity and primary energy supply is of great importance for the economic and social growth - of the Afghans. Further, In order to devise effective policy and planning, the Government of Afghanistan, donors, private sector actors, and civil society organizations need access to quality information and data about the current energy landscape in Afghanistan.

Electrifying is a long and challenging process that necessitates political stability, appropriate legislation and regulation, and international support. To provide electricity, the government must take up the opportunity to overcome the barriers by utilizing the ability to learn from the experience of other developing countries. The energy services should be reasonable, consistent, safe and environmental-friendly.

There are some strategies that can be taken for the betterment of the energy sector :

- Power generation strategy must focus on low cost energy generation, capacity utilization optimization, regulating the input cost, optimization of fuel mixture and its technology, and adoption of renewable energy sources.

- Proper implementation can help in improving the reliability of the energy system of the country.

- The strategy should conserve and optimize the utilization of electricity with a focus on demand management, load management and up-gradation of the technology by providing energy-efficient equipment

- Regulation -should aim at -balancing the - interest of all stakeholders and making energy sector commercially viable.

- For the growth of the energy sector, finance-related strategies must be adopted.

- Local manufacturing of renewable energy product must be implemented at the central level.

- The government should provide an energy planning process to create competition and stability for domestic and foreign investors.

- Promote energy efficiency by proper management of utilities distribution systems.

- Government and private sector units along with community should work together for achieving the long-term energy efficiency initiatives benefitting its citizens.

- A large amount of energy is consumed in buildings; therefore energy efficiency strategies should strictly implement in buildings.

\section{References}

1. M. A. Schreurs, J. Balanowski, Promoting socially and economically just energy transformations in Asia possibilities, challenges and the road ahead. Hanoi, (2017).

2. CSO, Afghanistan statistical yearbook 2016-2017. Kabul : Central Statistics, (2017).

3. World Bank, Afghanistan development brief, the implications of Afghanistan's 2014 security transition. World Bank Report, (2019).

4. NEPA, Second national communication. Kabul: national environmental protection agency, 2-30, (2017).

5. ADB, Proposed multi-tranche financing facility Islamic republic of Afghanistan: energy supply improvement investment program. Manila: report and recommendation of the president to the board of directors, (2015).

6. D. Bochkarev, Afghanistan reconnected linking energy supplies to consumers in Asia. Eastwest Institute, (2014).

7. MEW, Afghanistan investment opportunities in energy sector. Kabul: Da Afghanistan Breshna Sherkat, (2017).

8. ANDS, Energy Sector Strategy (2007/08 - 2012/13). Afghanistan National Development Strategy Secretariat, (2008).

9. World Bank, Afghanistan renewable energy development issues and options. Washington, D.C, (2018).

10. World Bank, Afganistan economic updated, Washington D.C, (2013). 
11. DABS, Afghanistan energy information center. Kabul : Da Afghanistan Breshna Sherkat, (2016).

12. ICE, inter-ministerial commission for energy, electricity imports (2016). Available on https://Sites.Google.Com/Site/Iceafghanistan/Electrici ty-Supply/Electricity-Imports)

13. ICE, Inter-ministerial commission for energy transmission and distribution, (2015). Available on Https://Sites.Google.Com/Site/Iceafghanistan/Transm ission-And-Distribution-Development

14. MEW, Draft power sector strategy for ANDS. Kabul : ministry of energy and water, (2007).

15. World Bank, Afghanistan overview. Kabul: The World Bank. (2013).

16. ICE, Number of DABS electricity connection. interministerial commission for energy, (2016). Available on Https://Sites.Google.Com/Site/Iceafghanistan/ Electricity-Supply/Connections)

17. IRENA, Renewable capacity statistics. Masdar: Internaitonal renewable energy agency, (2018).

18. MEW, Renewable energy policy. Kabul: Ministry of Energy and water, (2015).

19. ADB, Power sector master plan, islamic republic of Afghanistan. Asian development bank. (2010) Available on: Https://Www.Adb.Org/Sites/Default /Files/Project-Document/76570/43497-012-AfgTacr.Pdf
20. MEW, Ministry of Energy and water. Kabul: Afghanistan national integrated energy policy,, (2016).

21. USAID, Advisor to the secretariat of the interministerial commission for Energy, Kabul: United States aid for international development , (2010).

22. MEW. Call for expression of interest (EoI) for implementation of $100 \mathrm{Mw}$ grid connected.Kabul : ministry of energy and water, Renewal, (2016).

23. ADB, Sector assessment, energy.Asian development bank, (2015).

24. NEPA, Second national communication. Kabul : national environmental protection agency, 2-30, (2017).

25. MEW, Afghanistan investment opportunities in energy sector, Kabul : DABS, (2017).

26. A. Al-Mofleh, S. Taib, M. A. Mujeebu, W. Salah, Analysis of sectoral energy conservation in Malysia. J. Energy, (34) 733-739, (2009). 